\title{
Analisis Permintaan Wisatawan Millennial Terhadap Obyek Wisata Sungai Koran Melalui Faktor Sosioekonomi dan Lokasi
}

\author{
Muh. Indra ${ }^{1}$, Irawan ${ }^{2}$, Vera Monica Nababan ${ }^{3}$ \\ ${ }^{1}$ Program Pascasarjana Universitas Palangka Raya \\ ${ }^{2,3}$ Fakultas Ekonomi dan Bisnis Universitas Palangka Raya
}

\author{
Keywords: \\ tourist demand; \\ millennial tourists; \\ age; \\ income; \\ distance; \\ travel cost
}

\section{ABSTRACT}

\begin{abstract}
This study aims to determine the effect of socioeconomic factors (age, age, and income) and factors related to location (cost and distance) of millennial tourists. This type of research is explanations and field surveys with a sample non-probability technique of 150 respondents. The analysis technique uses multiple linear regression. The results showed that the cost of travel, age of income and distance had a positive and significant effect on the number of millennial tourists visiting the attractions of the Sungai Koran Park, Sebangau National Park. The implication of this study is the development of the tourism infrastructure of the Koran River as one of the national tourism destinations to the Province of Central Kalimantan.
\end{abstract}

Abstrak:. Penelitian ini bertujuan untuk mengevaluasi Program OSC dari sisi mekanisme mendapatkan beasiswa melalui program online scholarship competition, dan kendala yang dihadapi ketika menyaring para calon beasiswa dan manfaatnya sebagai bagian partisipasi pada visi generasi emas Indonesia 2045. Observasi lapangan dan wawancara digunakan untuk mengumpulkan data, dan teknik PESTEL dan SWOT dikolaborasi untuk mengindentifikasi berbagai kelebihan, kekurangan, peluang dan tatangan yang dihadapi. Hasil studi di lapangan menunjukkan bahwa program ini memiliki kemudahan, namun perlu dilakukan perluasan jaringan kerjasama perguruan tinggi lebih banyak lagi. Selain itu, OCS memiliki legitimasi dari Kemenristek dikti dan Kemendikbud. OSC memiliki target market sangat jelas, segmented dan mencakup Nasional dan dapat meningkatkan citra Perguruan Tinggi Swasta dan sponsorship yang menjadi mitra.

\section{Pendahuluan}

Provinsi Kalimantan Tengah dikarunia Tuhan kekayaan sumberdaya alam hutan yang luar biasa potensinya. Taman Nasional Tanjung Putting dan Bukit Raya adalah wujud dari upaya pemerintah melindungi kekayaan alam di Kalimantan Tengah. Demikian pula halnya dengan upaya pemerintah menetapkan Taman Nasional Sebangau (TNS) di Kalimantan Tengah dimaksudkan untuk mempertahankan keanekaragaman hayati dan ekosistem khas yang ada di dalamnya. Status TNS baru pada tingkat penunjukkan dari kawasan eks HPH dinaikkan status fungsinya menjadi Kawasan Pelestarian Alam (KPA). Kawasan Sebangau ditunjuk menjadi Taman Nasional Sebangau pada tanggal 
19 Oktober 2004, sesuai dengan SK Menteri Kehutanan No.423/Menhut-II/2004 seluas sekitar 568.700 ha, mengalami perubahan melalui SK Menteri Kehutanan Nomor : 529/Menhut-II/2012 dengan luas menjadi 542.141 ha. Lembaga yang sangat aktif mempersiapkan penunjukkan alih fungsi menjadi TNS ini adalah WWF Kalimantan Tengah, yang kemudian didukung oleh Pemerintah Provinsi kalimantan Tengah, Kabupaten Katingan, dan Kabupaten Pulang Pisau.

Penilaian terhadap suatu kawasan wisata memiliki peranan yang dapat menentukan pengembangan oyek wisata tersebut yang mencangkup berbagai faktor, baik itu nilai ekonomi, sosial maupun nilai politik. Menurut Ward et.al (2000, dalam Raharjo, XXX) metode penilaian khususnya untuk mengukur nilai ekonomi wisata alam yang banyak dipakai adalah Travel Cost Method (TCM). Metode Biaya Perjalanan (Travel Cost Method; TCM) sebagai seuah metode yang pertama kali digunakan untuk menduga nilai ekonomi sebuah komoditas yang tidak memiliki nilai pasar (nonmarket goods).

Obyek wisata Sungai Koran adalah salah satu obyek wisata yang dikembangkan dalam kawasan Taman Nasional Sebangau dan cukup ramai dikunjungi oleh wisatawan domestik dan wisatawan mancanegara. Kawasan obyek wisata Sungai Koran merupakan ekosistem hutan rawa gambut. dimana terdapat ekosistem danau atau sungai air hitam yang unik serta menjadi habitat untuk 25 jenis mamalia, 116 jenis burung borneo, 36 jenis ikan, serta sekitar 166 jenis flora (Balai TNS, 2014). Hasil kajian LIPI (2007) menyatakan bahwa Taman Nasional Sebangau, termasuk obyek wisata Sungai Koran merupakan salah satu Taman Nasional yang memiliki keanekaragaman flora dan fauna yang tinggi (biodiversity) karena memiliki memiliki 809 jenis flora, yang termasuk dalam 128 suku (16 jenis diantaranya belum teridentifikasi). Salah satu bentuk pengembangan dan pengelolaan Taman Nasional Sebangau adalah untuk kegiatan riset dan rekreasi (ekowisata). Produk wisata ini telah mendorong wisatawan mancanageara dan domestik untuk berkunjung ke obyek wisata Sungai Koran di Taman Nasional Sebangau.

Perkembangan kunjungan wisatawan ke Taman Nasional Sebangau, termasuk ke oyek wisata Sungai Koran selama Tahun 2005 - 2018 diuraikan dalam Gambar 1 berikut :

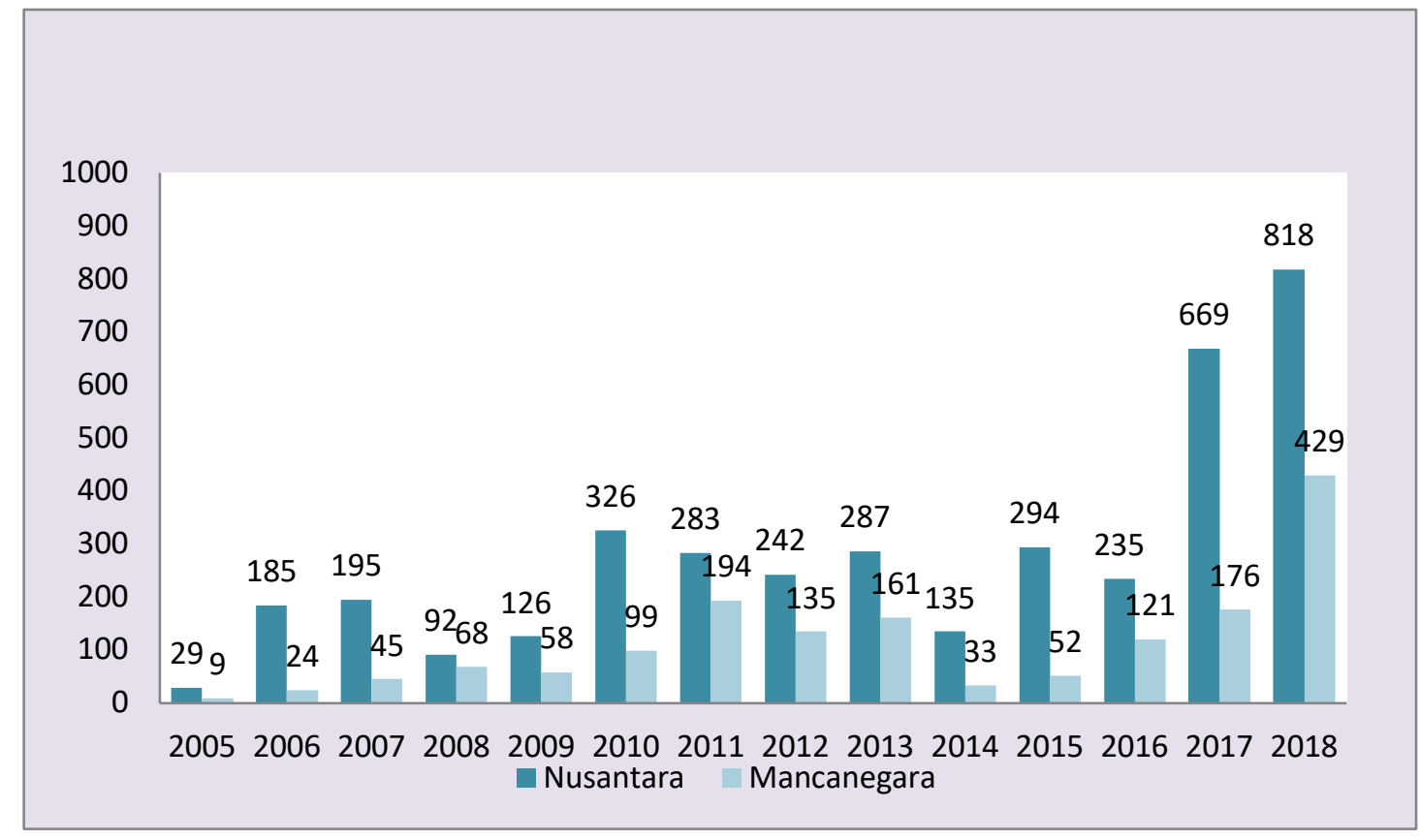

Gambar 1. Jumlah Pengunjung TN Sebangau 2005-2018

Sumber: Balai Taman Nasional Sebangau-WordPress.com 2007

Gambar 1 di atas menunjukkan bahwa pada tahun 2005 adalah jumlah kunjungan wisatawan Nusantara maupun Mancanegara ke Taman Nasional Sebangau masih relative sedikit. Selanjutnya 
pada tahun-tahun berikutnya jumlah kunjungan wisatawan semakin meningkat seiring dengan semakin baiknya beberapa infrastruktur wisata yang ada di setiap obyek wisata, termasuk obyek wisata Sungai Koran. Secara umum dalam lima tahun terakhir (2014-2018) jumlah kunjungan wisatawan mengalami peningkatan. Total wisatawan yang berkunjung ke Taman Nasional Sebangau pada tahun 2014 adalah seanyak 168 orang, meningkat menjadi seesar 1.247 orang pada tahun 2018, atau terjadi peningkatan yang signifikan sebesar $86,53 \%$. Peningkatan jumlah kunjungan ke obyek wisata Sungai Koran Taman Nasional Sebangau seiring dengan dimulainya perencanaan dan pengembangan obyek wisata melalui peningkatan kualitas faktor suplai obyek wisata seperti transportasi, atraksi, akomodasi, dan fasilitas pendukung lainnya menjadi salah faktor penentu meningkatnya permintaan wisatawan terhadap oyek wisata Sungai Koran di Taman Nasional Sebangau.

\section{Permintaan Obyek Wisata}

Pariwisata merupakan aktivitas manusia mengunjungi suatu daerah dalam kurun waktu tertentu atau sementara untuk menikmati berbagai obyek dan atraksi wisata. Obyek wisata dan atraksi wisata adalah satu aspek suplai yang menjadi faktor penting dalam manajemen pariwisata. Pengembangan obyek wisata didasarkan pada dukungan dan potensi daerah yang akan ditetapkan sebagai kawasan wisata. Kebijakan pengembangan pembangunaan pariwisata merupakan salah satu kebutuhan penting bagi setiap layanan pariwisata, sehingga obyek wisata memiliki daya tarik dan pesona bagi para wisatawan. Menurut Irawan dkk (2017), strategi pengembangan kawasan obyek wisata di Taman Nasional Sebangau adalah strategi pertumbuhan terhadap potensi yang dimiliki dan merupakan kekuatan dan peluang yang ada sebagai obyek wisata yang diminati oleh wisatawan domestik dan wisatawan mancanegara.

Potensi yang dimiliki oleh setiap obyek wisata adalah sebagai dasar untuk merencanakan strategi pengemangannya untuk menjadi sebuah obyek wisata yang memiliki daya tarik. Daya tarik tersebut akan banyak ditentukan oleh produk wisata yang dapat ditawarkan kepada wisatawan, seperti atraksi, akomodasi, refreshing (food and drink), fasilitas transportasi, dan fasilitas pendukung lainnya (Bagyono, 2005). Atraksi wisata iasanya menjadi faktor pendorong atau Demand Side dari setiap calon wisatawan untuk melakukan kunjungan ke obyek wisata.

Kepuasan wisatawan menikmati berbagai atraksi wisata yang ada di obyek wisata akan tercapai apabila semua uang yang dibelanjakan untuk memenuhi peutuhannya selama berwisata, dapat memberi kepuasan sesuai dengan apa yang diinginkannya. Tingkat kepuasan yang didapatkan oleh setiap wisatawan dalam menikmati setiap atraksi yang ditawarkan oleh sebuah obyek wisata akan member pengaruh terhadap permintaan wisatawan terhadap obyek wisata.

Faktor sosial ekonomi adalah karakteristik yang menentukan kualitas hidup dalam suatu masyarakat. Faktor ini dapat mempengaruhi perilaku, sikap, tren, selera dan gaya hidup individu atau kelompok. Pendidikan, pendapatan, dan juga pekerjaan, adalah parameter utama status sosial ekonomi (Omare et al., 2019). Faktor lainnya termasuk pekerjaan sampingan, kesehatan dan gaya hidup, kualitas lingkungan (lingkungan), dan jarak lokasi tujuan. Karakteristik sosial-demografis turis seperti pendapatan rumah tangga tahunan, usia, dan status pekerjaan ditemukan secara signifikan mempengaruhi permintaan pariwisata internasional. Faktor politik dan karakteristik tujuan juga merupakan penentu penting dari permintaan pariwisata internasional. (Takele, 2019).

\section{Biaya Perjalanan dan Jumlah Kunjungan Wisatawan}

Garrod dan Willis, (1999) menyatakan bahwa konsep dasar dari metode travel cost adalah waktu dan pengeluaran biaya perjalanan (travel cost expenses) yang harus dibayarkan oleh para pengunjung untuk mengunjungi tempat wisata tersebut yang merupakan harga untuk akses ke tempat wisata. Dalam hal ini setiap wisatawan telah memperhitungkan sejumlah biaya yang merupakan pengeluaran biaya perjalanan wisata yang dilakukan dalam waktu tertentu. Hasil kajian ini didukung dan sejalan dengan pernyataan Garrod dan Willis bahwa pengeuaran biaya perjalanan wisatawan merupakan harga untuk sampai ke tempat wisata. Kaitannya dengan besarnya pengeluaran wisatawan dalam setiap perjalanan wisata menurut Indra dan Nurbani (2018) terdapat 
sekitar 35\% wisatawan millennial yang membelanjakan uangnya selama mengadakan wisata dalam satu obyek wisata adalah sebesar Rp. 1.000.000,- sampai dengan Rp. 3.000.000. Lebih lanjut Vanhove (2012) menyatakan bahwa faktor terpenting yang mendorong partisipasi dalam pariwisata adalah faktor ekonomi, dan kunci dari faktor-faktor ini adalah pendapatan.

Dalam konteks wisata berbiaya rendah, beberapa studi menemukan bahwa strategi low-cost dapat membuka pasar untuk peluang baru. Sebagai contoh, Moreno-Izquierdo et al. (2015) menemukan bahwa maskapai penerbangan berbiaya rendah dapat memodifikasi aliran wisatawan ke pasar baru, menjadikan pariwisata elemen pelengkap pengembangan sektor transportasi udara. Selain itu, Koo, Lim, dan Dobruszkes (2017) juga menemukan beberapa bukti untuk mendukung hubungan layanan udara berbiaya rendah dengan permintaan pariwisata. Berdasarkan uraian ini dapat dinyatakan bahwa biaya perjalanan merupakan komponen penting dalam pembentukan kunjungan wisatawan, dengan demikian hipotesis yang diajukan adalah:

$\mathrm{H}_{1}$ : Biaya Perjalanan Berpengaruh Signifikan Terhadap Kunjungan Wisatawan

\section{Umur dan Jumlah Kunjungan Wisatawan}

Perjalanan wisatawan ke suatu obyek wisata, dipengaruhi oleh factor pendorong seperti : motivasi dan keinginan individu itu sendiri dan adanya faktor penarik seperti daya tarik obyek dan atraksi wisata yang ditawarkan di suatu obyek wisata. Hal lain yang menjadi alasan dan motivasi setiap wisatawan, termasuk wisatawan millennial untuk melakukan perjalanan wisata karena ingin keluar dari rutinitas sehari-hari, menyegarkan pikiran, mencari sesuatu yang baru, memanjakan diri, bersenang-senang dan sebagainya. Usia merupakan salah satu faktor yang dapat mempengaruhi perilaku wisatawan.

Wang dan Davidson (2010) melakukan analisis analisis mikro pengeluaran wisatawan menunjukkan bahwa pengeluaran dipengaruhi oleh serangkaian karakteristik sosial-demografis yang kompleks dari para wisatawan (misalnya, jenis kelamin, usia, status perkawinan, tingkat pendidikan, pekerjaan, tempat tinggal, kebangsaan), latar belakang etnis, ukuran dan komposisi rumah tangga). Dalam tinjauan literature yang dilakukan oleh Brida dan Scuderi (2013) mencatat bahwa variabel dummy yang mewakili kelompok umur tertentu sangat sering digunakan dalam penelitian, tetapi ukuran dan kategori rujukan bervariasi antar penelitian. Pengaruh usia pada pengeluaran wisata ditambah dengan operasi berbiaya rendah, dengan pengunjung yang lebih muda menghabiskan lebih sedikit pengeluaran wisata (Silva et al., 2020). Berdasarkan penjelasan tersebut maka hipotesis yang diajukan adalah:

$\mathrm{H}_{2}$ : Usia Berpengaruh Signifikan Terhadap Kunjungan Wisatawan

\section{Pendapatan dan Jumlah Kunjungan wisatawan}

Menurut Oka (2008) ketika melakukan perjalanan wisata wisatawan akan menggunakan pendapatan bebas (disposible income) untuk keperluan wisata seperti hotel accomodation, food and beverages, transportations dan others (laundry, newspapers). Dalam hal ini variabel biaya perjalanan ke objek wisata Sungai Koran meliputi biaya transportasi, biaya retribusi masuk, biaya penginapan, biaya konsumsi, biaya dokumentasi, serta biaya-biaya lain yang relevan. Semua unsure biaya dimaksud dipengaruhi oleh kemampuan untuk membayar (Willingnes to Pay) sektor pariwisata yang digambarkan melalui biaya perjalanan (Travel Cost), yang berhubungan positif dengan pendapatan wisatawan dan anggaran rekreasi wisatawan. Maksudnay adalah jika terjadi penambahan pendapatan dan anggran rekreasi maka jumlah wisatawan akan meningkat. Vanhove (2012) lanjut membahas hubungan antara pendapatan dan permintaan wisata dimana ketika pendapatan meningkat sebesar 1 persen, permintaan untuk pariwisata meningkat lebih dari 1 persen. Didasarkan pada uraian tersebut maka hipotesis yang diajukan adalah:

$\mathrm{H}_{3}$ : Pendapatan Berpengaruh Signifikan Terhadap Kunjungan Wisatawan

\section{Jarak dan Jumlah Kunjungan Wisatawan}

Studi Sofronov Bogda (2018), menyatakan bahwa rata-rata 35 hari pertahun wisatawan millennial mengadakan perjalanan wisata dan melakukan pembayaran secara tunai. Merujuk pada 
hasil studi Sofronov Bogda (2018), dapat dikatakan bahwa perjalanan wisata kaum millennial ke berbagai obyek wisata tidak terlalu mempertimbangkan aspek harga dan jarak, tetapi yang berkaitan dengan hal-hal yang autentik, unik dan tempat-tempat yang masih asli/lestari. Kim dan Jang (2019) dalam studinya yang mengamati perilaku wisatawan berdasarkan durasi tempuh lokasi tujuan menemukan bahwa perjalanan sehari lebih sering dilakukan oleh wisatawan yang lebih muda. Mckercher (2018) menjelaskan bahwa pada dasarnya, siapa saja yang dapat melakukan perjalanan jarak pendek, tetapi tidak semua orang dapat melakukan perjalanan jarak jauh. Jarak, oleh karena itu, dapat secara efektif menyaring beberapa segmen, karena waktu yang lebih tinggi, biaya dan finansial yang terkait dengan usia, ukuran dan komposisi perjalanan, pendapatan, ketersediaan waktu, motif dan kemauan atau kemampuan untuk memasuki tujuan budaya yang berbeda. Khususnya, segmen usia muda yang memiliki keterbatasan waktu dan biaya cenderung memilih wisata jarak pendek. Sebaliknya, orang yang lebih tua, lebih berpendidikan, berpenghasilan lebih tinggi dengan ketersediaan waktu yang lama, atau backpacker muda tanpa kendala waktu lebih mungkin melakukan wisatawan jarak jauh. Dengan demikian dapat dinyatakan bahwa jarak merupakan salah satu faktor yang dapat mempengaruhi perilaku wisatawan. Didasarkan pada uraian tersebut maka hipotesis yang diajukan adalah:

$\mathrm{H}_{4}$ : Jarak Berpengaruh Signifikan Terhadap Kunjungan Wisatawan

\section{Metode}

\section{Desain Penelitian}

Penelitian ini bersifat deskriptif untuk mendeskripsikan atau menggambarkan fenomena atau hubungan antar fenomena yang diteliti dengan sistematis, faktual dan akurat. Penelitian deskriptif digunakan bertujuan agar peneliti dapat menggambarkan dengan lebih baik sifat-sifat yang diketahui keberadaannya serta relevan dengan variabel-variabel yang diteliti. Pendekatan dalam penelitian ini merupakan pendekatan kuantitatif dan kualitatif untuk menggambarkan tanggapan responden terhadap obyek berdasarkan kuesioner yang diberikan. Penelitian ini akan difokuskan pada lokasi obyek wisata Sungai Koran dalam lingkup SPTN-I Sebangau Hulu dalam wilayah Taman Nasional Sebangau. Secara administratif pemerintahan obyek wisata Sungai Koran berada di Kelurahan Kereng Bangkirai Kecamatan Sebangau, Kota Palangka Raya.

\section{Populasi dan Sampel}

Populasi dalam penelitian ini adalah keseluruhan sampel yang diambil dengan metode simple random sampling dengan pengambilan sampel secara acak sesuai dengan tujuan penelitian. Selanjutnya setelah sampel dikelompokkan dilakukan penarikan sampeldengan prosedur accidental sampling. Dalam pengambilan sampel wisatawan dan masyarakat lokal mengacu menggunakan rumus Slovin dengan batas kesalahan $5 \%$ dengan tingkat akurasi data $95 \%$ sehingga jumlah sampel sebanyak 150 responden. Responden dipilih secara simple random sampling yakni pengambilan secara acak sederhana berdasarkan jumlah penduduk dan pengunjung di lokasi penelitian.

Teknik pengumpulan data dilakukan dengan dua cara, yaitu: (a) Metode survey dan pengamatan meliputi berbagai hal yang menyangkut pengamatan kondisi fisik dan aktivitas pada lokasi penelitian. Selain itu observasi lapangan dilakukan untuk mengobservasi lokasi, baik kondisi fisik maupun keadaan masyarakat daerah penelitian dengan terjun langsung ke lapangan. b) Teknik kuesioner adalah bentuk pertanyaan terstruktur yang diberikankepada responden sesuai dengan masalah penelitian. Perangkat kuisioner digunakan sebagai salah satu instrumen untuk memperoleh informasi yang terkait dengan persepsi masyarakat terhadap pengembangan ekowisata. Selain metode survei dan pengamatan lapangan, juga digunakan metode kepustakaan untuk menghimpun data-data yang sudah dipublikasi oleh instansi maupun lembaga yang terkait dengan variabel penelitian. Data-data yang dikumpulkan adalah data-data dari lembaga yang berhubungan dengan penelitian seperti Balai Taman Nasional Sebangau dan Dinas Pariwisata. Studi kepustakaan ini digunakan untuk memperoleh data sekunder. Batas toleransi kesalahan ini dinyatakan dengan 
persentase. Semakin kecil toleransi kesalahan, semakin akurat sampel menggambarkan populasi. Dalam hal ini jumlah sampel yang diambil sebagai responden adalah sebanyak 150 responden.

\section{Teknik Analisis Data}

Data primer yang sudah terkumpul selanjutnya dilakukan analisis untuk mendapatkan gambaran tentang hubungan antar variabel. Metode analisis regresi berganda, dengan pendekatan Ordinary Least Squares (OLS) sebagai metode analisis yang dipilih (Sri Mulyono, 2000). Analisis permintaan wisatawan millennial berupa kunjungan wisatawan ke oyek wisata Sungai Koran dikaitkan dengan variabel umur pengunjung, penghasilan rata-rata dan jarak, sehingga formulasi hubungan antar variabel dalam bentuk fungsi dan regresi diuraikan sebagai berikut:

$J K=f(B P, U, P h, J)$

Keterangan :

$\mathrm{JK}=$ Jumlah kunjungan obyek wisata Sungai Koran

$\mathrm{BP}=$ Biaya perjalanan tempat wisata berupa biaya transportasi, biaya konsumsi, karcis masuk, biaya parkir dan biaya lain-lain

$U \quad=$ Umur pengunjung

$\mathrm{Ph} \quad=$ Penghasilan rata - rata per bulan pengunjung

$\mathrm{J}=\quad=$ Jarak tempat tinggal pengunjung dengan obyek wisata Sungai Koran

$\mathrm{JK}=\beta_{0}+\beta_{1} \mathrm{BP}+\beta_{2} \mathrm{U}+\beta_{3} \mathrm{Ph}+\beta_{4} \mathrm{~J}+\mathrm{e}$

\section{Hasil dan Pembahasan}

Setelah terpenuhinya asumsi klasik sebagai syarat penggunakan regresi linear berganda seperti uji multilinieritas, heterokedastisitas dan uji normalitas residual, maka model regresi dapat diinterpretasikan. Hasil analisis regresi selanjutnya dijelaskan sebagai berikut:

\section{Uji F (Uji Goodness of fit)}

Uji-F merupakan pengujian signifikansi keseluruhan yang menunjukkan apakah model regresi linier yang digunakan dapat memberikan kesesuaian yang lebih baik terhadap data daripada model yang tidak mengandung variabel independen. Secara umum, uji-F dalam regresi membandingkan kesesuaian model linier yang berbeda. Tidak seperti uji-t yang hanya dapat menilai satu koefisien regresi pada suatu waktu, uji-F dapat menilai beberapa koefisien secara bersamaan.

Uji F dalam penelitian ini adalah 154.371 dan nilai sig $0.000<0.05$. Dapat dinyatakan bahwa uji $\mathrm{F}$ ini signifikan secara statistik yang berarti model ini memiliki kekuatan penjelas

\section{Koefisien Determinasi $\left(\mathbf{R}^{2}\right)$}

Dari hasil regresi yang dilakukan dengan menggunakan SPSS 21 dihasilkan pengaruh variabel Biaya Perjalanan, Umur, Pendapatan dan Jarak terhadap Jumlah Kunjungan Obyek Wisata Sungai Koran Taman Nasional Sebangau dengan nilai adj. $\mathrm{R}^{2}$ sebesar 0.861 . Artinya bahwa nilai koefisien determinasi (R-Squared) dengan angka 0,861 menunjukkan bahwa $86 \%$ Jumlah Kunjungan wisatawan dipengaruhi oleh empat variabel bebas (biaya perjalanan, umur, pendapatan dan jarak) dan sisanya $143 \%$ dipengaruhi oleh variabel lain diluar model.

\section{Persamaan Regresi dan pengujian hipotesis}

Berdasarkan pada hasil koefisien regresi (B) yang ditampilkan pada Tabel 2, maka diperoleh persamaan sebagai berikut: $Y=1,327+1,541 X_{1}+0,034 X_{2}+6.638 X_{3}+0.025 X_{4}+e_{i}$ 
Apabila variabel $X$ yaitu Biaya Perjalanan, Umur, Pendapatan dan Jarak sama dengan nol maka nilai dari variabel $Y$ (Jumlah Kunjungan wisatawan) sebesar 1.327. Apabila Biaya Perjalanan naik sebesar 1 Rupiah maka akan meningkatkan Jumlah Kunjungan wisatawan ke Sungai Koran sebesar 1,541. Apabila Umur bertambah sebanyak 1 tahun maka akan meningkatkan Jumlah Kunjungan wisatawan ke obyek wisata Sungai Koran sebesar 0,034. Apabila pendapatan perkapita naik sebesar 1 Rupiah maka akan meningkatkan Jumlah Kunjungan wisatawan ke oye wisata Sungai Koran sebesar 6,638. Selanjutnya apabila Jarak naik sejauh 1 kilometer, maka akan meningkatkan Jumlah Kunjungan wisatawan ke obyek wisata Sungai Koran sebesar 0.025 .

Tabel 2. Hasil Analisis Regres

\begin{tabular}{lllll}
\hline \multirow{2}{*}{ Model } & \multicolumn{3}{l}{ Unstandardized Coefficients } & \multirow{2}{*}{ Sig. } \\
\hline 1. (Constant) & B & Std. Error & & t \\
Biaya Perjalanan (X1) & 1,327 &, 379 & 3,501 &, 001 \\
$\quad$ Umur (X2) & 1,541 &, 675 & 2,282 &, 000 \\
$\quad$ Pendapatan (X3) &, 034 &, 009 & 3,882 &, 000 \\
Jarak (X4) & 6,638 & 3,271 & 2,029 &, 010 \\
&, 025 &, 008 & 2,965 &, 004 \\
Adjusted R Square &, 861 & & \\
F-statistik & 154,371 & \multicolumn{3}{c}{ Sumber : Data Primer, diolah, 2019}
\end{tabular}

\section{Pengaruh Biaya Perjalanan $\left(X_{1}\right)$ terhadap Jumlah Kunjungan Wisatawan $(Y)$}

Hasil analisis data menunjukkan variabel biaya perjalanan $\left(\mathrm{X}_{1}\right)$ dengan nilai $\mathrm{t}$-hitung $>\mathrm{t}$-tabel yakni sebesar 2,282>1,661 pada tingkat kepercayaan $95 \%(\alpha=0,05)$ dimana nilai signifikansinya lebih kecil dari $0,05(0,000<0,05)$ maka $\mathrm{H}_{0}$ ditolak dan $\mathrm{H}_{1}$ diterima, artinya bahwa secara parsial variabel Biaya Perjalanan $\left(\mathrm{X}_{1}\right)$ berpengaruh signifikan dan positif terhadap Jumlah Kunjungan wisatawan $(\mathrm{Y})$.

Selanjutnya hasil estimasi yang diuraikan pada tabel 3, menunjukkan bahwa biaya perjalanan berpengaruh positif terhadap jumlah kunjungan wisatawan, dimana nilai koefisien regresi $b_{1}=1,541$. Artinya bahwa setiap kenaikan biaya perjalanan sebesar 1 Rupiah maka akan meningkatkan jumlah kunjungan wisatawan ke oyek wisata Sungai Koran sebanyak 1,541orang dengan asumsi variabel lain tetap atau konstan. Studi ini mendukung pendapat Garrod dan Willis, (1999), Studi Indra dan Sri Nurbani (2018); Moreno-Izquierdo et al. (2015); dan Koo, Lim, dan Dobruszkes (2017) yang juga menemukan bukti hubungan antara biaya perjalanan pada perilaku wisatawan.

\section{Pengaruh Umur $\left(\mathrm{X}_{2}\right)$ terhadap Jumlah Kunjungan Wisatawan $(\mathrm{Y})$}

Hasil analisis data menunjukkan variabel umur $\left(\mathrm{X}_{2}\right)$ diperoleh nilai $\mathrm{t}_{\text {-hitung }}>\mathrm{t}$-tabel yakni sebesar $3,882>1,661$ pada tingkat kepercayaan $95 \%(\alpha=0,05)$ dimana nilai signifikansinya lebih kecil dari $0,05(0,000<0,05)$ maka $\mathrm{H}_{0}$ ditolak dan $\mathrm{H}_{1}$ diterima, artinya bahwa secara parsial variabel umur $\left(\mathrm{X}_{2}\right)$ berpengaruh signifikan dan positif terhadap Jumlah Kunjungan wisatawan (Y). Selanjutnya hasil estimasi yang diuraikan pada tabel 3 menunjukkan variabel umur berpengaruh positif terhadap jumlah kunjungan wisatawan dengan nilai koefisien regresi $b_{2}=0,034$. Angka menunjukkan bahwa apabila umur bertambah sebanyak 1 tahun maka akan meningkatkan jumlah kunjungan ke obyek wisata Sungai Koran sebanyak 0,034 orang dengan asumsi variabel lain tetap atau konstan.

Perjalanan wisatawan ke suatu obyek wisata, dipengaruhi oleh factor pendorong seperti : motivasi dan keinginan individu itu sendiri dan adanya faktor penarik seperti daya tarik obyek dan atraksi wisata yang ditawarkan di suatu obyek wisata. Hal lain yang menjadi alasan dan motivasi setiap wisatawan, termasuk wisatawan millennial untuk melakukan perjalanan wisata karena ingin keluar dari rutinitas sehari-hari, menyegarkan pikiran, mencari sesuatu yang baru, memanjakan diri, bersenang-senang dan sebagainya. Studi ini mendukung temuan Wang dan Davidson (2010); Brida 
dan Scuderi (2013) dan Silva et al. (2020) yang membuktikan keterkaitan usia pada pilihan dan perilaku wisata.

\section{Pengaruh Pendapatan $\left(\mathrm{X}_{3}\right)$ terhadap Jumlah Kunjungan wisatawan $(\mathrm{Y})$}

Hasil analisis data menunjukkan variabel pendapatan $\left(X_{3}\right)$ diperoleh nilai $t_{\text {-hitung }}>t t_{\text {tabel }}$ yakni sebesar 2,029>1,661 pada tingkat kepercayaan $95 \%(\alpha=0,05)$ dimana nilai signifikansinya lebih kecil dari $0,05(0,010<0,05)$ maka $\mathrm{H}_{0}$ ditolak dan $\mathrm{H}_{1}$ diterima, artinya bahwa secara parsial variabel pendapatan $\left(\mathrm{X}_{3}\right)$ berpengaruh signifikan dan positif terhadap Jumlah Kunjungan wisatawan $(\mathrm{Y})$. Selanjutnya hasil estimasi yang diuraikan pada tabel 3 , menunjukkan bahwa variabel pendapatan berpengaruh positif terhadap jumlah kunjungan wisatawan dengan nilai koefisien regresi $b_{3}=6,638$. Artinya bahwa jika pendapatan perkapita naik sebesar 1 Rupiah maka akan meningkatkan Jumlah Kunjungan wisatawan ke obyek wisata Sungai Koran sebanyak 6,638 orang dengan asumsi variabel lain tetap atau konstan.

Studi ini mendukung temuan Oka (2008) yang menyatakan ketika melakukan perjalanan wisata wisatawan akan menggunakan pendapatan bebas (disposible income) untuk keperluan wisata seperti hotel accomodation, food and beverages, transportations dan others (laundry, newspapers). Dalam hal ini variabel biaya perjalanan ke objek wisata Sungai Koran meliputi biaya transportasi, biaya retribusi masuk, biaya penginapan, biaya konsumsi, biaya dokumentasi, serta biaya-biaya lain yang relevan. Semua unsure biaya dimaksud dipengaruhi oleh kemampuan untuk membayar (Willingnes to Pay) sektor pariwisata yang digambarkan melalui biaya perjalanan (Travel Cost), yang berhubungan positif dengan pendapatan wisatawan dan anggaran rekreasi wisatawan.

\section{Pengaruh Jarak $\left(\mathrm{X}_{4}\right)$ Terhadap Jumlah Kunjungan Wisatawan $(\mathrm{Y})$}

Hasil analisis menunjukkan bahwa variabel jarak $\left(\mathrm{X}_{4}\right)$ diperoleh nilai $\mathrm{t}_{\text {-hitung }}>\mathrm{t}$-tabel yakni sebesar 2,965 > 1,661 pada tingkat kepercayaan 95\% $(\alpha=0,05)$ dimana nilai signifikansinya lebih kecil dari $0,05(0,004<0,05)$ maka $\mathrm{H}_{0}$ ditolak dan $\mathrm{H}_{1}$ diterima, artinya bahwa secara parsial variabel jarak $\left(\mathrm{X}_{4}\right)$ berpengaruh signifikan dan positif terhadap Jumlah Kunjungan wisatawan $(\mathrm{Y})$. Selanjutnya berdasarkan hasil estimasi yang diuraikan pada tabel 3, menunjukkan bahwa variabel pendapatan berpengaruh positif terhadap jumlah kunjungan wisatawan dengan nilai koefisien regresi $\left.b_{4}=0,025\right)$. Artinya bahwa jika jarak naik sejauh 1 kilometer maka akan meningkatkan Jumlah Kunjungan wisatawan sebanyak 0,025 orang dengan asumsi variabel lain tetap atau konstan.

Penelitian ini mendukung studi Sofronov Bogda (2018) yang menyatakan bahwa rata-rata 35 hari pertahun wisatawan millennial mengadakan perjalanan wisata dan melakukan pembayaran secara tunai. Merujuk pada hasil studi Sofronov Bogda (2018), dapat dikatakan bahwa perjalanan wisata kaum millennial ke berbagai obyek wisata tidak terlalu mempertimbangkan aspek harga dan jarak, tetapi yang berkaitan dengan hal-hal yang autentik, unik dan tempat-tempat yang masih asli/lestari.

\section{Simpulan}

Penelitian ini bertujuan untuk mengevaluasi faktor yang mempengaruhi kunjungan wisatawan pada lokasi Sungai Koran di Taman Nasional Sebangau, kota Palangka Raya. Faktor tersebut meliputi factor sosio-ekonomi (biaya, pendapatan, dan usia) dan factor terkait lokasi yaitu jarak. Hasil analisis menunjukkan bahwa biaya perjalanan, umur, pendapatan dan jarak berpengaruh positif dan signifikan terhadap jumlah kunjungan wisatawan millennial ke obyek wisata Sungai Koran di Taman Nasional Sebangau. Faktor dominan yang berpengaruh terhadap perintaan wisatawan millennial ke obyek wisata Sungai Koran adalah biaya perjalanan dan pendapatan wisatawan.

Memperhatikan cukup tingginya permintaan wisatawan millennial yang berkunjung ke obyek wisata Sungai Koran, Taman Nasional Sebangau, maka menjadi urgent bagi pemerintah Kota Palangka Raya dan Manajemen Balai Taman Nsional Sebangau untuk meningkatkan kemampuan infrastruktur obyek wisata Sungai Koran untuk menyongsong kunjungan wisatawan, termasuk 
wisatawan millennial yang ingin menikmati keunikan atraksi wisata yang ada di kawasan wisata Sungai Koran.

\section{Daftar Pustaka}

Bagyono. 2005. Pariwisata dan Perhotelan. Edisi Juni 2007. Bandung

Balai Taman Nasional Sebangau. 2007. http://wordpress.com. 2007. Diunduh pada tanggal 25 Maret 2019.

Kim, H. R., Yi, C., \& Jang, Y. 2019. Relationships among overseas travel, domestic travel, and day trips for latent tourists using longitudinal data. Tourism Management, 72, 159-169.

Koo, T. T., Lim, C., \& Dobruszkes, F. 2017. Causality in direct air services and tourism demand. Annals of Tourism Research, 67, 67-77.

McKercher, B. 2018. The impact of distance on tourism: a tourism geography law. Tourism geographies, 20(5), 905-909.

Moreno, L., Ramon, A., \& Pedreño, A. 2015. The development of low-cost airlines and tourism as a competitiveness complementor: effects, evolution and strategies. Journal of Spatial and Organizational Dynamics, 3(4), 262-274.

Nugraha, I.F dan Nurbani, S. 2018. Citilink Journey Promotional Design. 5th Bandung Creative Movement International Conference on Creative Industries 2018 (5th BCM 2018). Advances in Social Science, Education and Humanities Research, volume 19. Atlantis Press.

Irawan, Alexandra Hukom, Mansur Afifi, Emelia. 2017. Opportunity and Challenge of Development of Ecotourism in the Sebangau National Park Central Kalimantan towards Sustainable Development. Proceeding of International Conference. Managing Growth for Sustainable tourism Development. Indigenus, authentic and Halal Tourism. Penerbit BP2EB Fakultas Ekonomi dan Bisnis Universitas Mataram. 2017.

Omare, M., Kiage, O., Akama, J., \& Sulo, T. 2019. Socioeconomic factors hindering domestic tourism consumption in Kenya: the case of Nakuru, Mombasa and Nairobi towns.

Silva, F. J. F., Câmara, G. F. M., Vieira, J. A. C., \& Santos, C. A. S. M. 2020. Is the spending behaviour of tourists affected by low-cost carriers' operation? Some empirical evidence. Tourism Management Perspectives, 33, 100630.

Sofronov Bogda. 2018. Millennials : A New Trend for The Tourism Industri. Annals of Spiru Haret University. Economics Series. Issue 3/2018. ISSN : 2393-1795, ISSN-L : 2068-6900.

Takele, Y. S. (2019). International Tourism demand and determinant Factor Analysis in ethiopia. International Journal of Systems and Society (IJSS), 6(1), 27-51. 